\title{
Physiological functions should be considered as true end points of nutritional intervention studies
}

\author{
L. Genton ${ }^{1,2}$, W. van Gemert ${ }^{1}$, C. Pichard ${ }^{2}$ and P. Soeters ${ }^{1 *}$ \\ ${ }^{1}$ Department of Surgery, University Hospital, P. Debyelaan, 25, PO Box 5800, 6202 AZ Maastricht, The Netherlands \\ ${ }^{2}$ Department of Clinical Nutrition, University Hospital, Geneva, Switzerland
}

\begin{abstract}
With the beginning of this millennium it has become fashionable to only follow 'evidencebased' practices. This generally-accepted approach cruelly negates experience or intelligent interpretation of pathophysiology. Another problem is that the great 'meta-analysts' of the present era only accept end points that they consider 'hard'. In the metabolic and nutritional field these end points are infection-related morbidity and mortality, and all other end points are considered 'surrogate'. The aim of this presentation is to prove that this claim greatly negates the contribution of more-fundamentally-oriented research, the fact that mortality has multifactorial causes, and that infection is a crude measure of immune function. The following problems should be considered: many populations undergoing intervention have low mortality, requiring studies with thousands of patients to demonstrate effects of intervention on mortality; nutrition is only in rare cases primary treatment, and in many populations is a prerequisite for survival rather than a therapeutic modality; once the effect of nutritional support is achieved, the extra benefit of modulation of the nutritional support regimen can only be modest; cost-benefit is not a valid end point, because the better it is done the more it will cost; morbidity and mortality are crude end points for the effect of nutritional intervention, and are influenced by many factors. In fact, it is a yes or no factor. In the literature the most important contributions include new insights into the pathogenesis of disease, the diminution of diseaserelated adverse events and/or functional improvement after therapy. In nutrition research the negligence of these end points has precluded the development and validation of functional end points, such as muscle, immune and cognitive functions. Disability, quality of life, morbidity and mortality are directly related to these functional variables. It is, therefore, of paramount importance to validate functional end points and to consider them as primary rather than surrogate end points.
\end{abstract}

Clinical end points: Muscle function: Immune function: Cognitive function: Evidence-based medicine

Nutritional depletion, or protein-energy malnutrition, has been associated with a high rate of infection-related morbidity and mortality (Sullivan, 1995). The association is implicit because nutritional depletion has been defined in general as a situation of diminished uptake or intake of nutrition leading to diminished physiological function. In the metabolic and nutritional field (septic) morbidity and mortality are generally considered as the only hard end points. However, a substantial amount of work shows that: (1) physiological dysfunction increases the risk of septic complications and mortality (Rantanen et al. 2000; Dewey \& Saz, 2001; Cabioglu et al. 2002); (2) nutritional markers are highly correlated with alterations of muscular, immune and cognitive functions (Gogos et al. 1998; Pearson et al. 2001; Gosker et al. 2003); (3) nutritional support may improve physiological function (Hiroshige et al. 1998; Bourdel-Marchasson et al. 2001; Magri et al. 2003). These findings raise the question of whether physiological functions can be used as hard end points in nutritional studies.

At present, the diagnosis of nutritional depletion and the follow-up of patients with a precarious nutritional state rarely include the assessment of physiological function. Although it appears obvious that nutritional state and function are linked, lack of clearly defined and validated functional tests may explain why they are rarely used. Furthermore, the assessment of physiological functions

*Corresponding author: Professor Dr P. B. Soeters, fax +31 43 3875473, email pb.soeters@ah.unimaas.nl 
may be expensive, time-consuming or may require an active participation of the patient, which cannot be obtained in patients with, for example, critical illness, dementia or physical handicaps. Thus, at present, functional tests are not used in clinical practice but are predominantly used in research.

However, physiological function may be a more reliable and useful end point than infection-related morbidity and mortality. Indeed, morbidity and mortality are influenced by many factors. They are, therefore, crude end points of nutritional intervention and may not be sensitive enough to detect the benefits of nutritional support. The assessment of morbidity and mortality in interventional studies that include individuals with a low mortality rate requires very large populations. Moreover, the use of mortality as the end point in nutritional studies appears illogical, as nutrition is generally a prerequisite for survival and not a therapeutic modality.

The present article will discuss the role of physiological function as a 'surrogate' for morbidity and mortality. It reviews the link between physiological function and mortality, and between nutritional depletion and physiological function, and reports the impact of nutritional support on physiological function. The focus is on the importance of nutritional depletion and the effect of total energy intake, and not on isolated nutritional deficiencies. It will not only depart from the apparently hard data in the literature but also highlight how personal ambition and economy skew the approach to research, data interpretation and publication.

\section{Evidence-based practice}

In clinical practice it has become fashionable to demand care that is based on evidence. In the classification of evidence clinical experience is only rated as level 4 , while randomised controlled trials and meta-analyses are rated as level 1 (Harbour \& Miller, 2001). Recommendations deduced from randomised controlled trials and metaanalyses are rated as level A and supposedly furnish the objective undeniable truth. Unfortunately, this supposition is flawed for at least four reasons:

1. product research tends to be directed by industry, which encourages investigators to embellish positive results, not to publish negative data or not to publish data that cannot be explained exclusively as a result of nutritional intervention (Daly et al. 1992). Since many investigators rely financially on industry to carry out research, it may be difficult for them to remain honest and unbiased;

2. positive results are required in order to be successful in healthcare-related careers, because they potentiate funding and further growth of the research group and its publications;

3. since negative studies cannot easily be published, the literature abounds in positive studies, which skew the meta-analyses;

4. data interpretation of clinical studies made in one centre by a small number of experienced investigators is usually difficult. Retrieving data from studies made by other investigators in variable environments is likely to introduce major bias and generate hazardous conclusions.

The unchanging pattern of evidence-based medicine has created in the minds of many healthcare professionals an unhealthy freedom to do as they like when no evidence is available. This approach has created as much harm as benefit. For example, consider the adage that it has never been proven in the intensive care unit that nutritional support is of any benefit'. All researchers have had the frustrating experience that patients have died from depletion when they were not fed adequately for prolonged periods of time. As a result of that generally-felt undeniable truth no medical ethical committee would ever allow carrying out a research study in which one group is deliberately starved for a prolonged period of time. However, the absence of this type of study precludes proof of efficacy, which in turn allows some clinicians to claim that it has never been proven that artificial nutrition is any good in the intensive care setting. In summary, the randomised controlled trial is not the one and only route to the truth, but good clinical studies may still have their value, as will be discussed.

\section{How should studies be carried out and what should be the end points?}

At first sight mortality is an important end point, but it is less the 'yes or no' factor than is generally claimed. Obviously, there is virtue in promoting survival in the intensive care unit, and healthcare professionals promote survival but not necessarily quality of life, which is determined by functional ability, muscle force, cognitive function, clearance from disease or ability to live with disease without suffering. Thus, living shortly may sometimes bring more benefit to the patient than surviving for a longer time.

Mortality has numerous aetiologies in addition to nutritional depletion. Consequently, the result of nutritional intervention or modulation may be only modest. By choosing mortality as the end point, studies are embarked on that are doomed to yield indecisive results, because hundreds of patients are required to achieve statistical significance. It is here that the trouble starts. The difference may become statistically significant if an attempt is made to exclude patients with negative outcome by changing retrospectively the inclusion criteria, to prolong the length of observation and/or to perform post-hoc analyses that eventually increase the likelihood of accidental but statistically significant differences (Moore et al. 1992; Ziegler et al. 1992; Griffiths et al. 1997). Thus, stressing the importance of mortality as the best end point in nutrition research handicaps endeavours to demonstrate the efficacy of nutritional intervention strategies. Enthusiastic 'meta-analysts' such as Heyland and Koretz claim that the next hard end point is infectious morbidity.

Infectious morbidity truly reflects the success or failure of treatment, but it is a very crude measure of immune function. It suffers from limitations similar to those of mortality. Septic complications are determined by many 
factors, including the severity of primary disease, surgical technique, comorbidity, nutritional state and the extent of inflammation already present before surgery or admittance to the intensive care unit. Such end points therefore require very large study populations to reach statistical significance. In practice these numbers are difficult to achieve, leading to non-significant differences between groups as they are originally defined in the study protocol. In turn, this position urges the need to stretch the data, look for non-compliance or to perform post-hoc analyses. Even the most honest among researchers at times have felt this urge, and it requires very rigid control of the data analysis, preferably by exterior parties, to overcome this problem.

Furthermore, infection-related morbidity has not yet been clearly defined. Although papers that have reported effects on infection-related morbidity have been rated to furnish level-1 evidence, the criteria for infection-related morbidity have been badly defined (Daly et al. 1992; Ziegler et al. 1992). For example, selective decontamination of the gut and oro-pharynx has a beneficial effect on the incidence of ventilator-associated pneumonia but does not decrease mortality. However, true septic abdominal complications (abscesses, anastomotic leakage) or true pneumonias (pneumococci, staphylococci) ostentatiously increase length of stay, general health state and mortality. This disparity casts doubt on the validity or the criteria used to assess 'septic morbidity'. It is possible that it is colonisation that is being dealt with rather than infection. Thus, infection-related morbidity is an important, but badly-defined, outcome variable that is liable to overinterpretation or stretching of the data to achieve statistical significance.

It therefore appears justified to look for end points that are more directly related to the nutritional intervention and are part of the hypothesis. If it is hypothesised that glutamine has a beneficial effect on muscle protein kinetics, muscle endurance or/and strength should be employed as the end point. Also, as additional 'surrogate' end points it should be ascertained that the proposed effect on muscle protein kinetics is indeed operative and that increased muscle performance is achieved. This approach has several advantages. First, the direct target of the hypothesis is focused on and the effect of glutamine is therefore separated from the effects of other factors on mortality. This approach allows inclusion of fewer patients, which makes studies more 'do-able'. Second, the assessment of protein kinetics improves the scientific quality of the study, confirms the hypothesised mode of action and therefore contributes to the knowledge about metabolism. It even makes the improvement found in the functional end point more believable. The functions that can be considered are: muscle function; immune function; cognitive function, including mood. Unfortunately, the focus on mortality and (septic) morbidity has distracted researchers from the functional end points that are still badly defined.

The proposed approach assumes that only one factor is different when comparing the effect of modulation of the nutritional regimen. It is sad to conclude that multimodality nutritional intervention has taught researchers nothing about metabolism, despite all the money that has been invested, and is now subject to intensive political debate that will not resolve the issue. There is a belief in immunonutrition because the individual components appear to be beneficial in settings that have looked at functional end points such as inflammatory activity in Crohn's disease, vasodilatation in coronary disease or erectile dysfunction. The reason for the depressingly low scientific output of multi-modality immunonutrition is that from the very start the hypothesis of the intervention has been unclear. $n-3$ Fatty acids, arginine and RNA have been combined because they all potentially stimulate enterocyte proliferation and have trophic effects on the gut mucosa, which in turn may be beneficial in critically-ill patients. One misinterpretation has been that stimulation of proliferation or of protein synthesis is all by itself beneficial. However, enterocyte proliferation and protein turnover are low in stable healthy situations but accelerated in the case of mucosal damage, as in coeliac disease, Crohn's disease and other inflammatory conditions of the bowel. The next implicit hypothesis is that gut function has a major impact on overall health status of patients in intensive care. At present, the superiority of enteral nutrition over parenteral nutrition is less evident than it has been in the past. First, increased permeability of the gut as the cause of multiple organ failure is much debated, and second, the immunodepression ascribed to parenteral nutrition has most likely resulted from overfeeding and inadequate control of plasma glucose levels (Moore et al. 1992).

At present, n-3 fatty acids are considered to down regulate the acute-phase response and thus counteract trauma or infection. On the other hand, arginine stimulates the immune response. The underlying hypothesis for the efficacy of the combination of these compounds is therefore confusing, precluding deepening of insight into the working mechanism of these food substances when they show clinical benefit. In the literature there is similar confusion. In some studies intervention is considered beneficial because C-reactive protein decreases in the intervention group (Windsor et al. 1998), whereas in other studies a similar benefit is claimed because the levels of IL-6, a proinflammatory cytokine, increase (Santos et al. 1994).

All these considerations lead researchers to try to formulate functional end points, and to explore whether measures can be defined that are validated and can easily be used in clinical studies.

\section{Nutritional state and muscle function}

\section{Assessment of muscle function}

Protein-energy malnutrition affects the function of peripheral and respiratory muscles, which can be tested directly by measurement of muscle strength and endurance. Cable tensiometry and non-motorised dynamometry (e.g. handgrip strength) are used to assess static peripheral muscle strength, while the one-repetition maximum method, representing the maximum amount of weight lifted once during a standard weightlifting exercise, reflects dynamic strength (McArdle et al. 1996). Computer-assisted isokinetic methods additionally measure movement patterns as torques, accelerations and velocities of body segments 
(Keating \& Matyas, 1996), but their cost and complexity limit their use to research with small study populations. The strength of respiratory muscles can be assessed by measurements of maximal pressures generated during forced inspiratory and expiratory efforts (Ramirez-Sarmiento et al. 2002). Muscle endurance, which corresponds to the ability to maintain a specific isometric force or power level involving combinations of concentric and eccentric muscular contractions, can be tested by the methods mentioned earlier or by performance tests. Muscle function can also be evaluated indirectly through questionnaires on physical activity. These questionnaires provide information relating to functional ability, defined as the ability to perform daily activities without assistance, and thus on quality of life.

\section{Impaired muscle function as a cause of disability and mortality}

The relationship between muscle strength, disability and mortality has been explored mostly in the elderly. Peripheral muscle strength decreases naturally by $12-15 \%$ per decade from the fifth to the eighth decade in men, while the decline appears to occur later but at a faster rate in women (Hurley, 1995).

Several cross-sectional studies report a link between low muscle strength and the ability of the same limb to perform muscle labour (Lauretani et al. 2003; Canning et al. 2004; Ostchega et al. 2004). In longitudinal studies handgrip strength has been shown to predict the functional disability that appears 25 years later in men aged 45-68 years (Rantanen et al. 1999) and 4 years later in men aged 71-91 years (Giampaoli et al. 1999). Handgrip strength at hospital admission has also been shown to be a good predictor of reduced functional ability during a median hospital stay of $10 \mathrm{~d}$ (Humphreys et al. 2002). These findings imply that the strength of a single limb is an indicator of the whole body to perform muscle labour, and that there is a threshold of muscle strength loss under which disability occurs. On the basis of these findings Lauretani et al. (2003) have set up cut-off values of knee-extension torque and handgrip strength related to a walking speed $<0.8 \mathrm{~m} / \mathrm{s}$ or a walking ability $<1 \mathrm{~km}$ in $>1000$ subjects.

The association between strength and mortality has been extensively explored. Rantanen et al. (2000) have shown that in initially-healthy men aged 45-68 years $(n 6040)$ the mortality rate over a period of 30 years is $24 \cdot 8$ in the lowest tertile of handgrip strength, 18.5 in the middle tertile and 14.0 in the highest tertile. The same research group have found that in elderly moderately-disabled women handgrip strength in the lowest tertile predicts 5-year mortality relating to CVD and respiratory disease, independently of inflammation, poor nutritional status, physical inactivity and depression (Rantanen et al. 2003). Ethnicity does not appear to influence the association between strength and mortality. Indeed, handgrip strength is predictive of the 6-year mortality in 7286 Japanese men (Fujita et al. 1995) and of the 5-year mortality in 2488 older Mexican Americans (Al Snih et al. 2002). Interestingly, in the latter study the association between mortality and handgrip strength was found to remain after controlling for functional disability, assessed by the Katz activities of daily living scale and by the instrumental activities of daily living scale (Al Snih et al. 2002). The strength of the association may, however, vary according to gender, as suggested by Stenvinkel et al. (2002), who found that handgrip strength is predictive of the 3 -year mortality in men but not in women with end-stage renal disease.

Functional disability increases the risk of mortality. Corti et al. (1994) have shown an increased 4-year mortality associated with functional disability in $>4500$ subjects aged $\geq 71$ years. This finding that a higher rate of mortality is associated with disability has been confirmed recently in the elderly (Persson et al. 2002, von Strauss et al. 2003) and in patients with chronic obstructive pulmonary disease (Ranieri, 2001). However, none of these studies has provided detailed information about the causes of mortality. Kattainen et al. (2004) have found that disability is predictive of all-cause and CHD mortality in men and of all-cause mortality in women 15 years later. Similarly, disability in activities of daily living before myocardial infarction has been reported to be related to 6-month mortality after myocardial infarction (Vaccarino et al. 1997). However, the disabled subjects were older and suffered from higher comorbidity, which may explain the higher mortality rate in this group. Thus, disability appears to promote or aggravate the severity of CVD.

To summarise, muscle weakness predicts both functional disability and mortality. Several studies have shown the relationship between disability and mortality, but it is not yet convincingly established whether the pathophysiological mechanism of this link is muscle weakness or other factors such as inflammation, disease or cognitive alterations.

\section{Impaired muscle function as a result of nutritional depletion}

Suggested pathways for impaired muscle function include malnutrition, systemic inflammation and physical inactivity (Rantanen et al. 2003; Fig. 1). Studies of the relationship between muscle function and nutritional state have been performed in subjects with chronic diseases, the elderly and surgical patients.

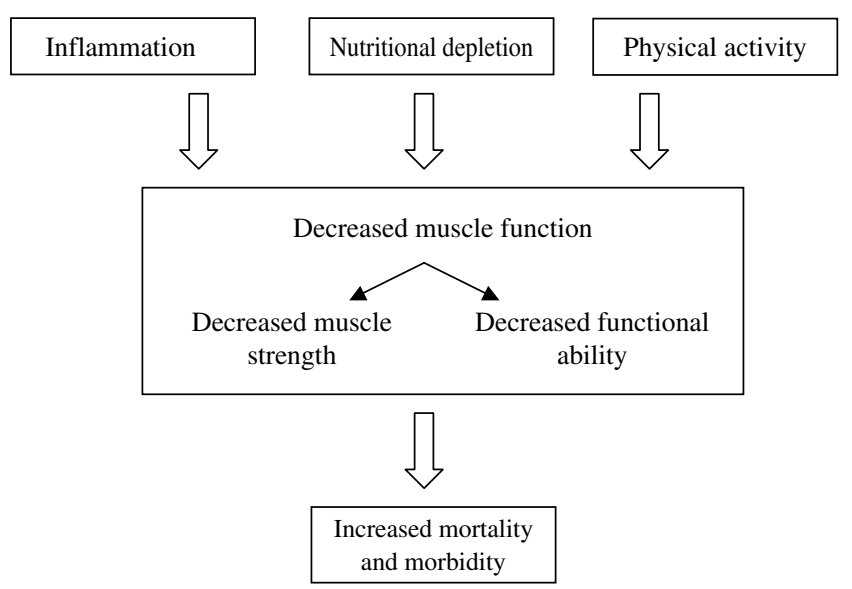

Fig. 1. Clinical factors influencing muscle function and effect on mortality and morbidity. 
The association between markers of malnutrition and muscle strength has been demonstrated in several recent studies. Serum albumin of patients with chronic renal failure has been found to be inversely correlated with knee extension and flexion strength, independently of protein intake or residual renal function (Cupisti et al. 2004). Fatfree mass has been shown to be positively associated with quadriceps and biceps strength in subjects with chronic obstructive pulmonary disease and chronic heart failure (Gosker et al. 2003). In elderly US outpatients stratified in tertiles according to their handgrip strength, the percentage of patients with unintentional weight loss is highest in the lowest tertile of handgrip strength (Rantanen et al. 2003). Maximal inspiratory and expiratory pressures are lower in patients with anorexia nervosa than in control subjects (Pieters et al. 2000). Since markers of nutritional state are also influenced by inflammation and disuse, these results do not, however, quantify the contribution to muscle weakness of pure nutritional depletion and the resulting muscle atrophy.

The link between malnutrition and functional disability has been mainly explored in the elderly. Functional disability has been related to low scores of the subjective global assessment or mini nutritional assessment (Persson et al. 2002), a low waist:hip ratio, low plasma albumin and transferrin levels (Romagnoni et al. 1999) and a low body cell mass (Zuliani et al. 2001). A longitudinal study has shown that in surgical and medical patients hospitalised for a median duration of $10 \mathrm{~d}$ a low score of the subjective global assessment, fat mass and handgrip strength predicts a decline in functional status (Humphreys et al. 2002). Zuliani et al. (2001) suggest three physiopathological mechanisms to explain the association between malnutrition, diagnosed as low body cell mass, and functional disability: (1) decreased body cell mass impairs functional ability through reduced muscle strength; (2) physical disability decreases body cell mass through inactivity; (3) inflammation reduces both body cell mass and functional ability. Indeed, chronic inflammation defined by elevated IL-6 plasma levels is inversely correlated with handgrip strength and total power in older subjects (Barbieri et al. 2003).

Although these studies used different methods and protocols to assess muscle function, diagnose malnutrition and follow nutritional state, they show an association between malnutrition, impaired muscle strength and functional disability.

\section{Effect of nutritional support on muscle function}

Studies relating to the consequences of nutritional intervention provide a better insight into the pathogenesis of muscle weakness and functional disability. Impaired muscle function appears $24 \mathrm{~h}$ after starvation of well-nourished subjects but muscle function returns to normal $6 \mathrm{~h}$ after the intake of a meal (Shizgal et al. 1986). Thus, nutritional supplementation appears to be sufficient to reverse muscle alterations in well-nourished subjects. This hypothesis has been verified in well-nourished patients undergoing elective surgery. The pre-operative intake of nutritional supplements $(1 \cdot 7-2 \cdot 1 \mathrm{MJ} \quad(400-500 \mathrm{kcal}) / \mathrm{d})$ limits the post-operative decrease in quadriceps strength (Henriksen et al. 2003). However, nutritional supplementation does not improve normal muscle function in well-nourished subjects. Nutritional supplementation of 1·5-2.1 MJ (350$500 \mathrm{kcal}) / \mathrm{d}$ during a period of 10 weeks-1 year has been shown to have no effect on muscle function and functional ability in well-nourished elderly subjects (Fiatarone et al. 1994; Wouters-Wesseling et al. 2003; Bunout et al. 2004).

The effect of nutritional supplementation on muscle function seems to be more controversial in depleted patients. A meta-analysis has shown that malnourished patients with chronic obstructive pulmonary disease receiving $\geq 2$ weeks of oral or enteral nutritional support $(1 \cdot 5-4 \cdot 2 \mathrm{MJ}$ $(350-1000 \mathrm{kcal}) / \mathrm{d})$ do not improve their respiratory muscle strength and $6 \mathrm{~min}$ walk test (Ferreira et al. 2000). This result has been confirmed by a more recent doubleblind study in which patients with chronic obstructive pulmonary disease were randomised to a carbohydrate-rich supplement $(2.4 \mathrm{MJ}(570 \mathrm{kcal}) / \mathrm{d})$ or a non-nutritive placebo for 7 weeks (Steiner et al. 2003). Underweight subjects (BMI $\leq 19 \mathrm{~kg} / \mathrm{m}^{2}$ ) with energy supplementation do not increase the time spent walking at $85 \%$ of the predicted $\mathrm{VO}_{2 \max }$, in contrast with those having a BMI $>19 \mathrm{~kg} / \mathrm{m}^{2}$. However, the number of subjects in the malnourished group was very small. The authors suggest that there is an exaggerated systemic inflammatory response, leading to higher energy expenditure, and an obligatory muscle catabolism, which cannot be overcome by increased energy intake. On the other hand, nutritional supplementation improves handgrip and respiratory muscle strength in malnourished patients with acute exacerbations of inflammatory bowel disease (Christie \& Hill, 1990), those awaiting liver transplantation (Le Cornu et al. 2000) and malnourished elderly subjects (Bourdel-Marchasson et al. 2001). These different outcomes most probably relate to the criteria used to define malnutrition as well as to inflammatory state and to the physical activity of the study populations.

Thus, nutritional support may improve muscle function, but only in malnourished subjects. Interestingly, this finding is in agreement with the results of a meta-analysis demonstrating that nutritional supplementation lowers mortality only in malnourished subjects (Potter et al. 2001).

\section{Nutritional state and immune function}

\section{Assessment of immune function}

Immune function has been studied less well in relation to nutritional state than muscle function. Protein-energy malnutrition affects both the cellular and humoral immunity, i.e. phagocytic function, cytokine production, generation of complement factors and the production of secretory immunoglobulin A (Chandra, 2002; Keusch, 2003). In present clinical routine immune function is rarely used as a marker of malnutrition, and in metabolic research immune function is mainly determined by the number and types of immune cells circulating in the bloodstream, the immunoglobulin levels, the delayed hypersensitivity response and the occurrence of infectious complications. 
Delayed hypersensitivity response is the response to intradermal application of an antigen to which a subject has already been exposed. It is evaluated by the size of swelling around the application of the antigen, usually $48 \mathrm{~h}$ after application (Calder \& Kew, 2002), and reflects cellmediated immunity. The foreign antigen is processed by monocytes and macrophages. These cells secrete IL-1 and IL-6, which stimulate clonal proliferation of antigenspecific T-cells, and also present the antigen to T-cells expressing a receptor specific for the antigen. T-cells (T-helper cells) in turn release cytokines to recruit other Tcells (T-cytotoxic cells) and macrophages or to directly damage the tissue. Unfortunately, the use of the delayed hypersensitivity response has largely been abandoned in clinical practice, although it is a true functional measure. The reason is probably that it gave a yes or no response and that its use is laborious. As a consequence it has not been further developed and validated as a graded measure of immune function.

\section{Impaired immune function as a cause of infection-related morbidity and mortality}

In surgical subjects a reduced delayed-type hypersensitivity skin test during sepsis has been associated with a higher sepsis-related mortality than a reactive hypersensitivity skin test (Christou et al. 1995). Patients with septic shock have a higher percentage of CD4+CD25+ T-cells than healthy volunteers, and the percentage of CD $4+\mathrm{CD} 25+\mathrm{T}$-cells is increased in non-survivors compared with survivors (Monneret et al. 2003). Le Tulzo et al. (2002) have found that patients on day 1 after septic shock exhibit higher lymphocyte apoptosis than control patients and that the survivors restore lymphocyte counts by day 6 in contrast with non-survivors. Cytokines undoubtedly play an essential role in the development of sepsis but the importance of plasma cytokine levels is unclear. Only circulating IL-6 appears to be correlated with the development and severity of sepsis. High serum levels of IL-6 predict the development of sepsis in patients after major surgery (Mokart et al. 2002) and in febrile patients (Groeneveld et al. 2003). Interestingly, Cabioglu et al. (2002) have measured leucocyte intracytoplasmic cytokines and have shown a decreased expression of T-lymphocyte-associated IL-6 and TNF $\alpha$ and monocyte-associated IL-10 and IL-12 in patients with severe sepsis. This result suggests that the circulating levels do not automatically reflect the production of cytokines and their role in the pathogenesis of sepsis. Thus, the link between cytokines and morbidity warrants further research at the cellular level rather than at the plasma level.

Numerous indices of infection have been related to a high risk of mortality. In patients with end-stage renal disease increased neutrophil counts and reduced lymphocyte counts have been found to be independent predictors of mortality (Pifer et al. 2002; Reddan et al. 2003). Other studies have specified the type of lymphocytes associated with survival. For example, in patients with HIV elevated CD4+ cell counts are associated with a high rate of survival (Melchior et al. 1999), although this result is controversial (Suttmann et al. 1995). In contrast, CD8+ cell counts are predictive of the 6-month mortality in severe alcoholic hepatitis (Mendenhall et al. 1995). Poor outcome is associated with lymphocyte apoptosis and reduced expression of pro-inflammatory and anti-inflammatory cytokines levels in patients with sepsis (Cabioglu et al. 2002; Le Tulzo et al. 2002), and with IL-6, a cytokine associated with age-related reduction in muscle mass, in the elderly (Cappola et al. 2003). The predictive value of delayed-type hypersensitivity response on postoperative morbidity and mortality is controversial (BeierHolgersen \& Brandstrup, 1999).

Thus, as expected, there is a clear relationship between immune function and infection-related morbidity and mortality. Confusion remains about the best immune marker to use as an indicator for immune competence and consequently as a predictor for morbidity and mortality.

\section{Impaired immune function as a result of nutritional depletion}

The effect of deficient energy intake on immune function is most evident in developing countries. Undernourished children present with a thymic atrophy with alteration of cellular immunity, resulting in a decreased production of secretory $\operatorname{IgA}$ in the mucosal-associated lymphoid tissue (Carli et al. 1990). Undernourished adults show an abolition of fever and leucocytosis in the case of infection, and only a moderate increase in the synthesis of acutephase proteins (Hasselmann et al. 2001).

Only a few recent studies have shown an association between immune dysfunction and nutritional depletion in patients with chronic disease. In 25661 patients undergoing haemodialysis a high lymphocyte count and low neutrophil count were found to be associated with high levels of serum albumin and creatinine (Reddan et al. 2003). In sixty patients with generalised malignancy classified as well-nourished or malnourished according to weight loss, serum albumin and transferrin as well as to the Karnofsky state of performance (Gogos et al. 1998), the absolute numbers of T-cells, the percentages of total Tcells and CD4+ T-cells were found to be lower in malnourished subjects than in well-nourished subjects. Nutritional state was not found to affect the number of $\mathrm{CD} 8+\mathrm{T}$-cells and the serum levels and production of IL-1, IL-6 and TNF $\alpha$.

Nutritional state is related to infectious complications in a vicious circle. Immune dysfunction caused by nutritional depletion leads to a high occurrence of infectious diseases, which in turn aggravate nutritional depletion. For example, depleted children suffer from frequent episodes of infectious disease, and kwashiorkor is precipitated by infection (Scrimshaw, 2003). Patients who are malnourished suffer from more-severe infection-related morbidity than those who are not malnourished, both in the case of acute renal failure (Fiaccadori et al. 1999) or with acquired megacolon (Vieira et al. 1996). Pre-operative weight loss before stricturoplasty (Dietz et al. 2001) and pre-operative serum albumin levels before gastrointestinal or spinal operations are also predictors of morbidity (Hu et al. 1998; Kudsk et al. 2003). Thus, to summarise, nutritional depletion impairs immune function. 
Table 1. Studies on the effect of energy intake on immune function

\begin{tabular}{|c|c|c|c|c|}
\hline Reference & Patients & Nutrition supplement & Length of intake & Outcome \\
\hline $\begin{array}{l}\text { Wouters-Wesseling } \\
\text { et al. (2003) }\end{array}$ & $\begin{array}{l}\text { Nineteen elderly } \\
\text { patients }\end{array}$ & $\begin{array}{l}\text { Oral supplement } v \text {. non- } \\
\text { energetic placebo }\end{array}$ & 7 months & $\begin{array}{l}\uparrow \text { Ig against influenza A/Beijing } \\
\text { and A/Sydney after vaccination }\end{array}$ \\
\hline \multirow[t]{2}{*}{$\begin{array}{l}\text { Schauder et al. } \\
\text { (2002) }\end{array}$} & $\begin{array}{l}\text { Sixty patients } \\
\text { undergoing large- } \\
\text { bowel surgery }\end{array}$ & $\begin{array}{l}\text { Post-operative TPN } \\
\text { v. no TPN }\end{array}$ & $5 d$ & $\uparrow$ IL-2, IFN- $\gamma$, TNF $\alpha$ \\
\hline & & & & $\downarrow$ IL-2 receptor expression \\
\hline $\begin{array}{l}\text { Van Bokhorst } \\
\text { et al. (2001) }\end{array}$ & $\begin{array}{l}\text { Forty-nine patients } \\
\text { undergoing head- } \\
\text { and-neck surgery }\end{array}$ & $\begin{array}{l}\text { Pre-operative tube feeding } \\
\quad v \text {. no tube feeding }\end{array}$ & $\begin{array}{l}\text { Nine pre-operative } \\
\text { days }\end{array}$ & $\begin{array}{l}\text { No effect on lymphocyte and } \\
\text { leucocyte counts, total T- and } \\
\text { B-cells, CD } 4+\text { cells, CD } 8+ \\
\text { cells, CD14+ cells, NK cells, } \\
\text { NK-like T-cells }\end{array}$ \\
\hline Chin et al. (2000) & 112 elderly patients & $\begin{array}{l}\text { Oral micronutrient- } \\
\text { enriched food } \\
v . \text { no supplement }\end{array}$ & 17 weeks & $\begin{array}{l}\text { No effect on delayed-type } \\
\text { hypersensitivity response }\end{array}$ \\
\hline $\begin{array}{l}\text { Powell et al. } \\
\text { (2000) }\end{array}$ & $\begin{array}{l}\text { Twenty-seven patients } \\
\text { with acute pancreatitis }\end{array}$ & $\begin{array}{l}\text { Early enteral feeding } \\
v . \text { no feeding }\end{array}$ & $4 d$ & $\begin{array}{l}\text { No effect on IL-6, TNF receptor-1, } \\
\text { CRP }\end{array}$ \\
\hline $\begin{array}{l}\text { Hiroshige et al. } \\
\text { (1998) }\end{array}$ & $\begin{array}{l}\text { Twenty-eight haemodialysis } \\
\text { patients }\end{array}$ & IDPN $v$. no IDPN & 1 year & $\uparrow$ Total lymphocyte counts \\
\hline $\begin{array}{l}\text { McCarter et al. } \\
\text { (1998) }\end{array}$ & $\begin{array}{l}\text { Patients undergoing } \\
\text { gastrointestinal } \\
\text { operations }\end{array}$ & $\begin{array}{l}\text { Oral supplement } \\
\text { v. no supplement }\end{array}$ & $\begin{array}{l}\text { Seven pre-operative } \\
\text { days }\end{array}$ & $\begin{array}{l}\text { No effect on lymphocyte prolife- } \\
\text { ration or monocyte function }\end{array}$ \\
\hline $\begin{array}{l}\text { Bozzetti et al. } \\
\text { (1995) }\end{array}$ & Nine cancer patients & TPN & Median $10 \mathrm{~d}$ & $\uparrow$ NK cell activity \\
\hline Sacks et al. (1995) & $\begin{array}{l}\text { Nine patients with } \\
\text { head injury }\end{array}$ & $\begin{array}{l}\text { TPN starting on day } 1 \\
\text { v. starting on day } 5\end{array}$ & $14 d$ & $\begin{array}{l}\uparrow \mathrm{IgM} \\
\uparrow \mathrm{CD} 4, \mathrm{CD} 4: \mathrm{CD} 8 \text { and } \mathrm{T} \\
\text { lymphocyte responsiveness } \\
\text { to Con } \mathrm{A}\end{array}$ \\
\hline $\begin{array}{l}\text { Bunker et al. } \\
\quad(1994)\end{array}$ & Thirty-nine elderly patients & $\begin{array}{l}\text { Oral supplement } v \text {. } \\
\text { no supplement }\end{array}$ & 12 weeks & $\begin{array}{l}\text { No effect on lymphocyte } \\
\text { population } \\
\text { Minimal effect on delayed-type } \\
\text { hypersensitivity response }\end{array}$ \\
\hline Fan et al. (1994) & $\begin{array}{l}\text { Sixty-four patients under- } \\
\text { going hepatectomy }\end{array}$ & $\begin{array}{l}\text { TPN peri-operative + oral } \\
\text { diet } v \text {. oral diet }\end{array}$ & $\begin{array}{l}14 \text { peri-operative } \\
\text { days }\end{array}$ & $\downarrow$ Infection-related morbidity \\
\hline
\end{tabular}

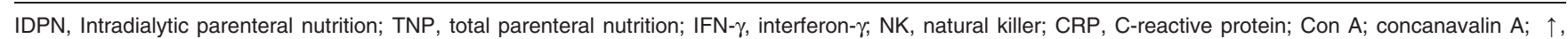
increase; $\downarrow$, decrease.

\section{Effect of nutritional support on immune function}

The effect of nutritional supplementation on immune function has been evaluated in different ways. Research has focused on the impact of energy intake, the route of feeding and the addition of isolated nutrients on immune function and outcome (Lin et al. 1998).

The effect of energy supplementation on the immune system is controversial (Table 1) and may be related to the baseline nutritional status. Indeed, in malnourished patients nutritional support appears to be beneficial (Bozzetti et al. 1995; Hiroshige et al. 1998). However, the effect of duration and quantity of supplementation, and the effect of the primary disease should not be neglected.

Interestingly, in moderately-malnourished patients under semi-elemental enteral or isonitrogenous isoenergetic parenteral support for at least $10 \mathrm{~d}$ there is a similar rise in lymphocyte counts, levels of complement factor $\mathrm{C} 3$, $\operatorname{IgA}$, IgG and $\operatorname{IgM}$, and a drop in the incidence of negative skin tests (Georgiannos et al. 1997). This finding is surprising since Christou et al. (1995) have found that parenteral nutrition does not correct the delayed-type hypersensitivity and many cellular immune functions tested in elective surgical patients. One hypothesis is that cellular immunity can be influenced differently depending on the route of feeding. Meta-analyses performed in critically-ill patients and patients with acute pancreatitis show that enteral nutrition leads to less infectious complications than parenteral nutrition (Gramlich et al. 2004; Marik \& Zaloga, 2004). In mice parenteral nutrition decreases $\operatorname{IgA}$ levels in intestinal and respiratory secretions, T- and B-cells in the Peyer's patches, CD4:CD8 in the intestinal lamina propria and the levels of IL-4 and IL10 levels in gut homogenates when compared with enteral nutrition (Genton \& Kudsk, 2003). However, the detrimental effect of parenteral nutrition on immune functions and infectious complications may be explained by total parenteral nutrition-induced hyperglycaemia, which is poorly controlled and increases the infectious risk.

Thus, nutritional supplementation may be essential for proper immune function in malnourished patients but the effect of the route of feeding on the immune dysfunction has not been clearly demonstrated in human subjects. Patients in whom immune functions predict morbidity and death need to be better defined in terms of nutritional state and disease. 


\section{Nutritional state and cognitive function}

\section{Assessment of cognitive function}

Neisser (1967) has stated that 'the term 'cognition' refers to all the processes by which the sensory input is transformed, reduced, elaborated, stored, recovered, and used. Such terms as sensation, perception, imagery, retention, recall, problem-solving, and thinking, among many others, refer to hypothetical stages or aspects of cognition'. Cognitive function can be assessed using clinical tests, neuropsychological tests, electroencephalography, clinical ratings and computerised test batteries. However, metabolic studies generally rely on clinical tests, such as the mini mental state examination, because they are easier and cheaper to perform than the other available tests (Riedel \& Jorissen, 1998).

\section{Impaired cognitive function as a cause of mortality}

Research on cognitive function is gaining increasing interest because the world population is getting older. Cognitive function has been related to age, educational level and profession (Schiel et al. 2003). A recent meta-analysis has shown that even low levels of cognitive impairment in the elderly lead to an increased risk of mortality, but cannot clearly identify the causes of death (Dewey \& Saz, 2001). Pneumonia and congestive heart failure have been found to be the primary cause of death in elderly patients with Alzheimer's disease (Janicki et al. 1999), but risk of death from stroke has also been associated with cognitive function (Gale et al. 1996). However, cognitive function at the time of performing a gastrostomy is not predictive of 1-year mortality (Bannerman et al. 2000).

A confounding factor for the relationship between cognitive function and mortality may be the presence of physical disability. However, mental impairment has been found in two studies to be a strong predictor of death independently of physical disability (De Andino et al. 1995; Noale et al. 2003).

\section{Impaired cognitive function as a result of nutritional depletion}

In many publications a correlation has been demonstrated between cognitive function and nutritional depletion. However, the cause-effect relationship is not yet clear, and nutritional depletion is potentially linked to cognitive impairment by a vicious circle similar to that associating nutritional depletion and immune function.

Dementia has been associated with nutritional depletion, defined by the mini nutritional assessment (Pearson et al. 2001; Magri et al. 2003). Elderly individuals with diminished cognitive function and functional ability have $>2$-fold higher risk of being nutritionally depleted (Pearson et al. 2001). Furthermore, the scales used to determine the severity of dementia (Bedford Alzheimer nursing severity scale or clinical dementia rating) can differentiate patients who are malnourished, according to the prognostic nutritional index, from those who are not malnourished (Bellelli et al. 1997). A decrease in cognitive function has also been related to weight loss and a low BMI
(Irving et al. 1999; Ponzer et al. 1999; Faxen-Irving et al. 2002). A longitudinal study conducted over a period of 5 years has shown that healthy elderly subjects with a BMI between 23 and $27 \mathrm{~kg} / \mathrm{m}^{2}$ have a 3.6 lower risk of cognitive decline in the subsequent 5 years (Deschamps et al. 2002). However, serum albumin, energy intake, serum creatinine and calf circumference are not associated with the mental component summary score of the SF-36 (questionnaire commonly used to assess quality of life) in 1545 haemodialysis patients (Allen et al. 2002).

Although there appears to be an association between cognitive function and nutritional markers, it remains unclear whether the disease itself, its pharmacological therapy, the functional disability or nutritional depletion leads to cognitive impairment.

\section{Effect of nutritional support on cognitive function}

Energy intake is associated with cognitive function. In 168 elderly subjects whose dietary intake was monitored using a food record for seven consecutive days individuals with satisfactory intellectual function (mini mental state examination $>28$ ) were generally found to have a greater intake than those with cognitive impairment (Requejo et al. 2003). These findings confirm earlier data from Ortega et al. (1997). Interestingly, these studies also indicate that the composition of the diet relates to cognitive function, suggesting that the intake of specific micro- or macronutrients may have a greater impact on cognitive function than total energy intake. Huijbregts et al. (1998) have calculated a healthy diet indicator, based on the World Health Organization (2003) guidelines for the prevention of chronic diseases, using dietary histories for 1049 elderly men from Finland, The Netherlands and Italy, and they concluded that a healthy diet might be associated with a better cognitive function. Similar results have been reported by Correa Leite et al. (2001).

Studies of the effect of nutritional supplementation on cognitive function are scarce. It has been found that 5 months of oral supplementation $(1.7 \mathrm{MJ}(410 \mathrm{kcal}) / \mathrm{d})$ of elderly subjects living in community-assisted housing results in weight gain but does not reduce the rate of decline in cognitive or functional capacity compared with subjects who received no supplementation (Faxen-Irving et al. 2002). In contrast, malnourished patients receiving dietary supplements for a mean duration of $45 \mathrm{~d}$ show an improvement in cognitive function, although the authors have concluded that there may be a confounding effect of pharmacological therapy for dementia (Magri et al. 2003). The impact of increased energy intake on cognitive function is not convincing so far, but it may prevent further deterioration of nutritional state in demented patients and thus lead to a lower rate of infectious events and mortality, as demonstrated by Gil Gregorio et al. (2003).

\section{Conclusion}

Large multi-centre studies addressing the clinical effects of nutritional interventions are useful if their power is sufficient and if their evaluation is independent of industrial 
pressure. It is suggested, however, that functional indices should be validated more thoroughly. They can be used in smaller studies and, when associated with surrogate end points, can give valuable information on the physiological and metabolic mechanisms of disease.

Nutritional depletion leads to alterations in muscle function and possibly cognitive and immune function. Nutritional supplementation can reverse some of the physiological dysfunctions occurring with nutritional depletion, but confounding variables are numerous. Nevertheless, because muscle strength consistently predicts morbidity and mortality, it is suggested that this variable is used as a hard marker of malnutrition-related morbidity and mortality. Immune function may be a welcome end point when sufficient knowledge exists about the benefit and/or harm of host response, and when variables evaluating the adequacy of immune function have been validated. Nutritional support may prevent cognitive decline in the elderly, but cognitive variables also clearly warrant further validation.

\section{References}

Allen KL, Miskulin D, Yan G, Dwyer JT, Frydrych A, Leung J \& Poole D (2002) Association of nutritional markers with physical and mental health status in prevalent hemodialysis patients from the HEMO study. Journal of Renal Nutrition 12, 160-169.

Al Snih S, Markides KS, Ray L, Ostir GV \& Goodwin JS (2002) Handgrip strength and mortality in older Mexican Americans. Journal of the American Geriatrics Society 50, 1250-1256.

Bannerman E, Pendlebury J, Phillips F \& Ghosh S (2000) A cross-sectional and longitudinal study of health-related quality of life after percutaneous gastrostomy. European Journal of Gastroenterology and Hepatology 12, 1101-1109.

Barbieri M, Ferrucci L, Ragno E, Corsi A, Bandinelli S, Bonafè M, Oliveri F, Giovagnetti S, Franceschi C, Guralnik JM \& Paolisso G (2003) Chronic inflammation and the effect of IGF-1 on muscle strength and power in older persons. American Journal of Physiology 284, E481-E487.

Beier-Holgersen R \& Brandstrup B (1999) Influence of early postoperative enteral nutrition versus placebo on cell-mediated immunity, as measured with the Multitest CMI. Scandinavian Journal of Gastroenterology 34, 98-102.

Bellelli G, Frisoni GB, Bianchetti A \& Trabucchi M (1997) The Bedford Alzheimer Nursing Severity scale for the severely demented: validation study. Alzheimer Disease and Associated Disorders 11, 71-77.

Bourdel-Marchasson I, Joseph PA, Dehail P, Biran M, Faux P, Rainfray M, Emeriau JP, Canioni P \& Thiaudiere E (2001) Functional and metabolic early changes in calf muscle occurring during nutritional repletion in malnourished elderly patients. American Journal of Clinical Nutrition 73, 832-838.

Bozzetti F, Cozzaglio L, Villa ML, Ferrario E \& Trabattoni D (1995) Restorative effect of total parenteral nutrition on natural killer cell activity in malnourished cancer patients. European Journal of Cancer 31A, 2023-2027.

Bunker VW, Stansfield MF, Deacon-Smith R, Marzil RA, Hounslow A \& Clayton BE (1994) Dietary supplementation and immunocompetence in housebound elderly subjects. British Journal of Biomedical Sciences 51, 128-135.

Bunout B, Barrera G, de la Maza P, Avendano M, Gattas V, Petermann M \& Hirsh S (2004) Effects of nutritional supplementation and resistance training on muscle strength in free living elders. Results of one year follow. Journal of Nutrition, Health and Aging 8, 68-75.

Cabioglu N, Bilgic S, Deniz G, Aktas E, Seyhun Y, Turna A, Gunay K \& Esen F (2002) Decreased cytokine expression in peripheral blood leukocytes of patients with severe sepsis. Archives of Surgery 137, 1037-1043.

Calder PC \& Kew S (2002) The immune system: a target for functional foods? British Journal of Nutrition 88, Suppl. 2, S165-S177.

Canning CG, Ada L, Adams R \& O'Dwyer NJ (2004) Loss of strength contributes more to physical disability after stroke than loss of dexterity. Clinical Rehabilitation 18, 300-308.

Cappola AR, Xue QL, Ferrucci L, Guralnik JM, Volpato S \& Fried LP (2003) Insulin-like growth factor I and interleukin-6 contribute synergistically to disability and mortality in older women. Journal of Clinical Endocrinology and Metabolism 88, 2019-2025.

Carli F, Webster J, Ramachandra V, Pearson M, Read M, Ford GC, McArthur S, Preedy VR \& Halliday D (1990) Aspects of protein metabolism after elective surgery in patients receiving constant nutritional support. Clinical Science 78, 621-628.

Chandra RK (2002) Nutrition and the immune system from birth to old age. European Journal of Clinical Nutrition 56, Suppl. 3, S73-S76.

Chin A, Paw MJ, de Jong N, Pallast EG, Kloek GC, Schouten EG \& Kok FJ (2000) Immunity and frail elderly: a randomized controlled trial of exercise and enriched foods. Medicine and Science in Sports and Exercise 32, 2005-2011.

Christie PM \& Hill GL (1990) Effect of intravenous nutrition on nutrition and function in acute attacks of inflammatory bowel disease. Gastroenterology 99, 730-736.

Christou NV, Meakins JL, Gordon J, Yee J, Hassan-Zahraee M, Nohr CW, Shizgal HM \& MacLean LD (1995) The delayed hypersensitivity response and host resistance in surgical patients. 20 years later. Annals of Surgery 222, 534-546.

Correa Leite ML, Nicolosi A, Cristina S, Hauser WA \& Nappi G (2001) Nutrition and cognitive deficit in the elderly: a population study. European Journal of Clinical Nutrition 55, 1053-1058.

Corti MC, Guralnik JM, Salive ME \& Sorkin JD (1994) Serum albumin level and physical disability as predictors of mortality in older persons. Journal of the American Medical Association 272, 1036-1042.

Cupisti A, Licitra R, Chisari C, Stampacchia G, D'Alessandro C, Galetta F, Rossi B \& Barsotti G (2004) Skeletal muscle and nutritional assessment in chronic renal failure patients on a protein-restricted diet. Journal of Internal Medicine 255, $115-124$.

Daly JM, Lieberman MD, Goldfine J, Shou J, Weintraub F, Rosato EF \& Lavin P (1992) Enteral nutrition with supplemental arginine, RNA, and omega- 3 fatty acids in patients after operation: immunologic, metabolic, and clinical outcome. Surgery 112, 56-57.

De Andino RM, Guillermo Conde-Santiago J \& Mendoza MM (1995) Functional disability and mental impairment as predictors of mortality in community-dwelling elderly Puerto Ricans. Puerto Rico Health Sciences Journal 14, 285-287.

Deschamps V, Astier X, Ferry M, Rainfray M, Emeriau JP \& Barberger-Gateau P (2002) Nutritional status of healthy elderly persons living in Dordogne, France, and relation with mortality and cognitive or functional decline. European Journal of Clinical Nutrition 56, 305-312.

Dewey ME \& Saz P (2001) Dementia, cognitive impairment and mortality in persons aged 65 and over living in the community: a systematic review of the literature. International Journal of Geriatric Psychiatry 16, 751-761. 
Dietz DW, Laureti S, Strong SA, Hull TL, Church J, Remzi FH, Lavery IC \& Fazio VW (2001) Safety and long term efficacy of stricturoplasty in 314 patients with obstructing small bowel Crohn's disease. Journal of the American College of Surgery 192, 330-337.

Fan ST, Lo CM, Lai EC, Chu KM, Liu CL \& Wong J (1994) Perioperative nutritional support in patients undergoing hepatectomy for hepatocellular carcinoma. New England Journal of Medicine 269, 30808-30811.

Faxen-Irving G, Andren-Olsson B, af Geijerstam A, Basun H \& Cederholm $T$ (2002) The effect of nutritional intervention in elderly subjects residing in group-living for the demented. European Journal of Clinical Nutrition 56, 221-227.

Ferreira IM, Brooks D, Lacasse Y \& Goldstein RS (2000) Nutritional support for individuals with COPD: a metaanalysis. Chest 117, 672-678.

Fiaccadori E, Lombardi M, Leonardi S, Rotelli CF, Tortorella G \& Borghetti A (1999) Prevalence and clinical outcome associated with preexisting malnutrition in acute renal failure: a prospective cohort study. Journal of the American Society of Nephrology 10, 581-593.

Fiatarone MA, O'Neill EF, Ryan ND, Clements KM, Solares GR, Nelson ME, Roberts SB, Kehayias JJ, Lipsitz LA \& Evans WJ (1994) Exercise training and nutritional supplementation for physical frailty in very elderly people. New England Journal of Medicine 330, 1769-1775.

Fujita Y, Nakamura Y, Hiraoka J, Kobayashi K, Sakata K, Nagai M \& Yanagawa H (1995) Physical-strength tests and mortality among visitors to health-promotion centers in Japan. Journal of Clinical Epidemiology 48, 1349-1359.

Gale CR, Martyn CN \& Cooper C (1996) Cognitive impairment and mortality in a cohort of elderly people. British Medical Journal 312, 608-611.

Genton L \& Kudsk KA (2003) Interactions between the enteric nervous system and the immune system: role of neuropeptides and nutrition. American Journal of Surgery 186, 253-258.

Georgiannos SN, Renaut AJ \& Goode AW (1997) Shortterm restorative nutrition in malnourished patients: pro's and con's of intravenous and enteral alimentation using compositionally matched nutrients. International Surgery 82, 301-306.

Giampaoli S, Ferrucci L, Cecchi F, Lo Noce C, Poce A, Dima F, Santaquilani A, Vescio MF \& Menotti A (1999) Hand-grip strength predicts incident disability in non-disabled older men. Age and Ageing 28, 283-288.

Gil Gregorio P, Ramirez Diaz SP \& Ribera Casado JM (2003) Dementia and nutrition. Intervention study in institutionalized patients with Alzheimer disease. Journal of Nutrition, Health and Aging 7, 304-308.

Gogos CA, Ginopoulos P, Salsa B, Apostolidou E, Zoumbos NC \& Kalfarentzos F (1998) Dietary omega-3 polyunsaturated fatty acids plus vitamin E restore immunodeficiency and prolong survival for severely ill patients with generalized malignancy: a randomized control trial. Cancer 82, 395-402.

Gosker HR, Kubat B, Schaart G, van der Vusse GJ, Wouters EF \& Schols AM (2003) Myopathological features in skeletal muscle of patients with chronic obstructive pulmonary disease. European Respiratory Journal 22, 280-285.

Gramlich L, Kichian K, Pinilla J, Rodych NJ, Dhaliwal R \& Heyland DK (2004) Does enteral nutrition compared to parenteral nutrition result in better outcomes in critically ill adult patients? A systematic review of the literature. Nutrition 20, 843-848.

Griffiths RD, Jones C \& Palmer TE (1997) Six-month outcome of critically ill patients given glutamine-supplemented parenteral nutrition. Nutrition 13, 295-302.
Groeneveld AB, Tacx AN, Bossink AW, van Mierlo GJ \& Hack CE (2003) Circulating inflammatory mediators predict shock and mortality in febrile patients with microbial infection. Clinical Immunology 106, 106-115.

Harbour R \& Miller J (2001) A new system for grading recommendations in evidence based guidelines. British Medical Journal 323, 334-336.

Hasselmann M, Schlossmacher P \& Kummerlen C (2001) Nutrition et immunite (Nutrition and immunity). In Traite de Nutrition Clinique de l'Adulte (Clinical Assessment of Nutrition of the Adult), pp. 82-88 [A Basdevant, M Laville and E Lerebours, editors]. Paris: Flammarion.

Henriksen MG, Hessov I, Dela F, Hansen HV, Haraldsted V \& Rodt SA (2003) Effects of preoperative oral carbohydrates and peptides on postoperative endocrine response, mobilization, nutrition and muscle function in abdominal surgery. Actc Anaesthesiologica Scandinavia 47, 191-199.

Hiroshige K, Iwamoto M, Kabashima N, Mutoh Y, Yuu K \& Ohtani A (1998) Prolonged use of intradialysis parenteral nutrition in elderly malnourished chronic haemodialysis patients. Nephrology, Dialysis, Transplantation 13, 2081-2087.

Hu SS, Fontaine F, Kelly B \& Bradford DS (1998) Nutritional depletion in staged spinal reconstructive surgery. The effect of total parenteral nutrition. Spine 23, 1401-1405.

Huijbregts PP, Feskens EJ, Rasanen L, Fidanza F, AlbertiFidanza A, Nissinen A, Giampaoli S \& Kromhout D (1998) Dietary patterns and cognitive function in elderly men in Finland, Italy and The Netherlands. European Journal of Clinical Nutrition 52, 826-831.

Humphreys J, de la Maza P, Hirsch S, Barrera G, Gattas V \& Bunout D (2002) Muscle strength as a predictor of loss of functional status in hospitalized patients. Nutrition 18, 616-620.

Hurley BF (1995) Age, gender, and muscular strength. Journal of Gerontology 50A, Special issue, 41-44.

Irving GF, Olsson BA \& Cederholm T (1999) Nutritional and cognitive status in elderly subjects living in service flats, and the effect of nutrition education on personnel. Gerontology $\mathbf{4 5}$, 187-194.

Janicki MP, Dalton AJ, Henderson CM \& Davidson PW (1999) Mortality and morbidity among older adults with intellectual disability: health services considerations. Disability and Rehabilitation 21, 284-294.

Kattainen A, Reunanen A, Koskinen S, Martelin T, Knekt P \& Aromaa A (2004) Disability predicted mortality in men but not women with coronary heart disease. Journal of Clinical Epidemiology 57, 513-521.

Keating JL \& Matyas TA (1996) The influence of subject and test design on dynamometric measurements of extremity muscles. Physical Therapy 76, 866-889.

Keusch GT (2003) The history of nutrition: malnutrition, infection and immunity. Journal of Nutrition 133, 336S-340S.

Kudsk KA, Tolley EA, DeWitt RC, Janu PG, Blackwell AP, Yeary S \& King BK (2003) Preoperative albumin and surgical site identify surgical risk for major postoperative complications. Journal of Parenteral and Enteral Nutrition 27, $1-9$.

Lauretani F, Russo CR, Bandinelli S, Bartali B, Cavazzini C, Di Iorio A, Corsi AM, Rantanen T, Guralnik JM \& Ferrucci L (2003) Age-associated changes in skeletal muscles and their effect on mobility: an operational diagnosis of sarcopenia. Journal of Applied Physiology 95, 1851-1860.

Le Cornu KA, McKiernan FJ, Kapadia SA \& Neuberger JM (2000) A prospective randomized study of preoperative nutritional supplementation in patients awaiting elective orthotopic liver transplantation. Transplantation 69, 1364-1369. 
Le Tulzo Y, Pangault C, Gacouin A, Guilloux V, Tribut O, Amiot L, Tattevin P, Thomas R, Fauchet R \& Drenou B (2002) Early circulating lymphocyte apoptosis in human septic shock is associated with poor outcome. Shock 18, 487-494.

Lin E, Kotani JG \& Lowry SF (1998) Nutritional modulation of immunity and the inflammatory response. Nutrition 14, $545-550$.

McArdle W, Katch F \& Katch V (1996) Exercise Physiology: Energy, Nutrition, and Human Performance. Baltimore, MA: Williams \& Wilkins.

McCarter MD, Gentilini OD, Gomez ME \& Daly JM (1998) Preoperative oral supplement with immunonutrients in cancer patients. Journal of Parenteral and Enteral Nutrition 22, 206-211.

Magri F, Borza A, del Vecchio S, Chytiris S, Cuzzoni G, Busconi L, Rebesco A \& Ferrari E (2003) Nutritional assessment of demented patients: a descriptive study. Aging: Clinical and Experimental Research 15, 148-153.

Marik PE \& Zaloga GP (2004) Meta-analysis of parenteral nutrition versus enteral nutrition in patients with acute pancreatitis. British Medical Journal 328, 1407.

Melchior JC, Niyongabo T, Henzel D, Durack-Bown I, Henri SC \& Boulier A (1999) Malnutrition and wasting, immunodepression, and chronic inflammation as independent predictors of survival in HIV-infected patients. Nutrition 15, 865-869.

Mendenhall CL, Moritz TE, Roselle GA, Morgan TR, Nemchausky BA, Tamburro CH, Schiff ER, McClain CJ, Marsano LS \& Allen JI (1995) Protein energy malnutrition in severe alcoholic hepatitis: diagnosis and response to treatment. The VA Cooperative Study Group \#275. Journal of Parenteral and Enteral Nutrition 19, 258-265.

Mokart D, Capo C, Blache JL, Delpero JR, Houvenaeghel G, Martin C \& Mege JL (2002) Early postoperative compensatory anti-inflammatory response syndrome is associated with septic complications after major surgical trauma in patients with cancer. British Journal of Surgery 89, 1450-1456.

Monneret G, Debard AL, Venet F, Bohe J, Hequet O, Bienvenu J \& Lepape A (2003) Marked elevation of human circulating $\mathrm{CD} 4+\mathrm{CD} 25+$ regulatory $\mathrm{T}$ cells in sepsis-induced immunoparalysis. Critical Care Medicine 31, 2068-2071.

Moore FA, Andrassy RJ, McArdle AH, Booth FV, MorgensteinWagner TB, Kellum JM, Welling RE \& Moore EE (1992) Early enteral feeding, compared with parenteral, reduces postoperative septic complications. The results of a metaanalysis. Annals of Surgery 216, 172-183.

Neisser U (1967) Cognitive Psychology. Englewood Cliffs, NJ: Prentice-Hall.

Noale M, Maggi S, Minicuci N, Marzari C, Destro C, Farchi G, Scafato E, Baldereschi M, Di Carlo A \& Crepaldi G (2003) Dementia and disability: impact on mortality. The Italian Longitudinal Study on Aging. Dementia and Geriatric Cognitive Disorders 16, 7-14.

Ortega RM, Requejo AM, Andres P, Lopez-Sobaler AM, Quintas ME, Redondo MR, Navia B \& Rivas T (1997) Dietary intake and cognitive function in a group of elderly people. American Journal of Clinical Nutrition 66, 803-809.

Ostchega Y, Dillon CF, Lindle R, Carroll M \& Hurley BF (2004) Isokinetic leg muscle strength in older Americans and its relationship to a standardized walk test: data from the National Health and Nutrition Examination Survey 1999-2000. Journal of the American Geriatrics Society 52, 977-982.

Pearson JM, Schlettwein-Gsell D, Brzozowska A, van Staveren WA \& Bjornsbo K (2001) Life style characteristics associated with nutritional risk in elderly subjects aged 80-85 years. Journal of Nutrition, Health and Aging 5, 278-283.

Persson MD, Brismar KE, Katzarski KS, Nordenstrom J \& Cederholm TE (2002) Nutritional status using mini nutritional assessment and subjective global assessment predict mortality in geriatric patients. Journal of the American Geriatrics Society 50, 1996-2002.

Pieters T, Boland B, Beguin C, Veriter C, Stanescu D, Frans A \& Lambert M (2000) Lung function study and diffusion capacity in anorexia nervosa. Journal of Internal Medicine $\mathbf{2 4 8}$ $137-142$.

Pifer TB, McCullough KP, Port FK, Goodkin DA, Maroni BJ, Held PJ \& Young EW (2002) Mortality risk in hemodialysis patients and changes in nutritional indicators: DOPPS. Kidney International 62, 2238-2245.

Ponzer S, Tidermark J, Brismar K, Soderqvist A \& Cederholm T (1999) Nutritional status, insulin-like growth factor-1 and quality of life in elderly women with hip fractures. Clinical Nutrition 18, 241-246.

Potter JM, Roberts MA, McColl JH \& Reilly JJ (2001) Protein energy supplements in unwell elderly patients - a randomized controlled trial. Journal of Parenteral and Enteral Nutrition 25, 323-329.

Powell JJ, Murchison JT, Fearon KC, Ross JA \& Siriwardena AK (2000) Randomized controlled trial of the effect of early enteral nutrition on markers of the inflammatory response in predicted severe acute pancreatitis. British Journal of Surgery 87, 1375-1381.

Ramirez-Sarmiento A, Orozco-Levi M, Barreiro E, Mendez R, Ferrer A, Broquetas J \& Gea J (2002) Expiratory muscle endurance in chronic obstructive pulmonary disease. Thorax 57, 132-136.

Ranieri P (2001) One-year mortality in elderly stable patients with COPD. Monaldi Archives of Chest Disease 56, 481-485.

Rantanen T, Guralnik JM, Foley D, Masaki K, Leveille S, Curb JD \& White L (1999) Midlife hand grip strength as a predictor of old age disability. Journal of the American Medical Association 281, 558-560.

Rantanen T, Harris T, Leveille SG, Visser M, Foley D, Masaki K \& Guralnik JM (2000) Muscle strength and body mass index as long-term predictors of mortality in initially healthy men. Journal of Gerontology 55A, M168-M173.

Rantanen T, Volpato S, Ferrucci L, Heikkinen E, Fried LP \& Guralnik JM (2003) Handgrip strength and cause-specific and total mortality in older disabled women: exploring the mechanism. Journal of the American Geriatrics Society 51, 636-641.

Reddan DN, Klassen PS, Szczech LA, Coladonato JA, O'Shea S, Owen WF Jr \& Lowrie EG (2003) White blood cells as a novel mortality predictor in haemodialysis patients. Nephrology, Dialysis, Transplantation 18, 1167-1173.

Requejo AM, Ortega RM, Robles F, Navia B, Faci M \& Aparicio A (2003) Influence of nutrition on cognitive function in a group of elderly, independently living people. European Journal of Clinical Nutrition 57, Suppl. 1, S54-S57.

Riedel WJ \& Jorissen BL (1998) Nutrients, age and cognitive function. Current Opinion in Clinical Nutrition and Metabolic Care 1, 579-585.

Romagnoni F, Zuliani G, Bollini C, Leoci V, Soattin L, Dotto S, Rizzotti P, Valerio G, Lotto D \& Fellin R (1999) Disability is associated with malnutrition in institutionalized elderly people. The I.R.A. Study. Istituto di Riposo per Anziani. Aging (Milano) 11, 194-199.

Sacks GS, Brown RO, Teague D, Dickerson RN, Tolley EA \& Kudsk KA (1995) Early nutrition support modified immune function in patients sustaining severe head injury. Journal of Parenteral and Enteral Nutrition 19, 387-392.

Santos AA, Rodrick ML, Jacobs DO, Dinarello CA, Wolff SM, Mannick JA \& Wilmore DW (1994) Does the route of feeding modify the inflammatory response. Annals of Surgery 220, 155-163. 
Schauder P, Rohn U, Schafer G, Korff G \& Schenk HD (2002) Impact of fish oil-enriched total parenteral nutrition on DNA synthesis, cytokine release and receptor expression by lymphocytes in the postoperative period. British Journal of Nutrition 87, S103-S110.

Schiel R, Bocklitz G, Braun A, Leppert K, Stein G \& Muller UA (2003) Cognitive function and quality of diabetes care in patients with type-2-diabetes mellitus in general practitioner practice. European Journal of Medical Research 8, 419-427.

Scrimshaw NS (2003) Historical concepts of interactions, synergism and antagonism between nutrition and infection. Journal of Nutrition 133, 316S-321S.

Shizgal HM, Vasilevsky CA, Gardiner PF, Wang WZ, Tuitt DA \& Brabant GV (1986) Nutritional assessment and skeletal muscle function. American Journal of Clinical Nutrition 44, 761-771

Steiner MC, Barton RL, Singh SJ \& Morgan MD (2003) Nutritional enhancement of exercise performance in chronic obstructive pulmonary disease: a randomised controlled trial. Thorax 58, 745-751.

Stenvinkel P, Barany P, Chung SH, Lindholm B \& Heimburger O (2002) A comparative analysis of nutritional parameters as predictors of outcome in male and female ESRD patients. Nephrology, Dialysis, Transplantation 17, 1266-1274.

Sullivan DH (1995) The role of nutrition in increased morbidity and mortality. Clinics in Geriatric Medicine 11, 661-674.

Suttmann U, Ockenga J, Selberg O, Hoogestraat L, Deicher H \& Muller MJ (1995) Incidence and prognostic value of malnutrition and wasting in human immunodeficiency virus-infected outpatients. Journal of Acquired Immune Deficiency Syndrome and Human Retrovirology 8, 239-246.

Vaccarino V, Berkman LF, Mendes de Leon CF, Seeman TE, Horwitz RI \& Krumholz HM (1997) Functional disability before myocardial infarction in the elderly as a determinant of infarction severity and postinfarction mortality. Archives of Internal Medicine 157, 2196-2204.

Van Bokhorst-de van der Shuer, von Blomberg-van der Flier BM, Kuik DJ, Scholten PE, Siroen MP, Snow GB, Quak JJ \& van Leeuwen PA (2000) Survival of malnourished head and neck cancer patients can be predicted by human leukocyte antigenDR expression and interleukin- 6/tumor necrosis factor-alpha response of the monocyte. Journal of Parenteral and Enteral Nutrition 24, 329-336.

Vieira MJ, Gama-Rodrigues JJ, Habr-Gama A, Faintuch J, Waitzberg DL \& Pinotti HW (1996) Preoperative assessment in cases of adult megacolon suffering from moderate malnutrition. Nutrition 12, 491-495.

Von Strauss E, Aguëro-Torres H, Kareholt I, Winblad B \& Fratiglioni L (2003) Women are more disabled in basic activities of daily living than men only in very advanced ages: A study on disability, morbidity, and mortality from the Kungsholmen Project. Journal of Clinical Epidemiology 56, 669-677.

Windsor AC, Kanwar S, Li AG, Barnes E, Guthrie JA, Spark JL, Welsh F, Guillou PJ \& Reynolds JV (1998) Compared with parenteral nutrition, enteral feeding attenuates the acute phase response and improves disease severity in acute pancreatitis. Gut 42, 431-435.

World Health Organization (2003) Diet, Nutrition and the Prevention of Chronic Diseases. Report of the Joint WHO/ FAO Expert Consultation. WHO Technical Report Series no. 916. Geneva: WHO.

Wouters-Wesseling W, Van Hooijdonk C, Wagenaar L, Bindels J, de Groot L \& Van Staveren W (2003) The effect of a liquid nutrition supplement on body composition and physical functioning in elderly people. Clinical Nutrition $\mathbf{2 2}$ 371-377.

Ziegler TR, Young LS, Benfell K, Scheltinga M, Hortos K, Bye $\mathrm{R}$ et al. (1992) Clinical and metabolic efficacy of glutamine-supplemented parenteral nutrition after bone marrow transplantation. A randomized, doubleblind, controlled study. Annals of Internal Medicine 116, 821-828.

Zuliani G, Romagnoni F, Volpato S, Soattin L, Leoci V, Bollini MC, Buttarello M, Lotto D \& Fellin R (2001) Nutritional parameters, body composition, and progression of disability in older disabled residents living in nursing homes. Journal of Gerontology 56A, M212-M216. 